\title{
Pengaruh Kecemasan Terhadap Konsentrasi Pada Atlet Renang Petrokimia Gresik
}

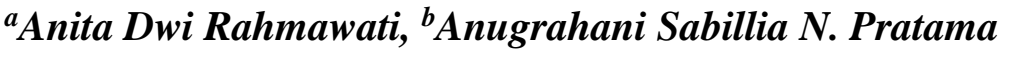 \\ ${ }^{a, b}$ Program Studi Psikologi, Universitas Negeri Surabaya, Indonesia \\ *Corresponding author: bellapratama@yahoo.co.id
}

\section{A R T ICLE INFO}

Article history:

Received 15 Mei 2018

Received in revised form 23 Juni

2018

Accepted 08 Agustus 2018

Keywords:

Anxiety, Concentration,

Swimming athletes

\begin{abstract}
A B S T R A C T
This study aims to determine whether there is an influence between anxiety with concentration in swimming athletes Petrokimia, Gresik. Hypothesis of work ( $\mathrm{Ha})$ proposed is There is an influence between anxiety with concentration in swimming athletes Petrokimia, Gresik. Subjects in this study were 30 swimming athletes. Data were collected using questionnaires in the form of anxiety scale and grid concentration scale. Data analysis technique using product moment correlation. The result of data analysis shows the correlation coefficient value of 0.132 with the significance level of 0.000 ( $p<0,005)$. These results indicate that there is a significant influence between anxiety with concentration on swimming athletes Petrokimia, Gresik, and positive values indicate a unidirectional relationship between two variables of anxiety and concentration. the higher the anxiety level of the athlete the lower the concentration that the athletes have, and vice versa.
\end{abstract}

\section{Pendahuluan}

Semakin majunya perkembangan zaman, maka semakin maju pula perkembangan ilmu olahraga. Olahraga kini menjadi suatu hal yang sangat sering diperbincangkan seluruh kalangan manusia mulai dari anak kecil sampai orang lanjut usia sekalipun sangat antusias pada olahraga. Berbagai macam jenis olahraga dapat dilakukan untuk menjaga kesehatan tubuh mereka. Olahraga yang dari dulu hingga saat ini sangat disukai oleh anak - anak adalah olahraga renang.

Renang merupakan sebuah olahraga yang dilakukan di air. Olahraga renang merupakan salah satu bentuk olahraga yang ringan karena sifatnya aerobik, yang dapat digunakan oleh lanak - anak hingga lanjut usia guna memperoleh kebugaran jasmani (Susanto, 2010). Cabang olahraga renang ini memiliki banyak manfaat sehingga banyak dari kalangan masyarakat menyukai cabang olahraga ini.

Meskipun renang banyak disukai oleh kalangan masyarakat tetapi Indonesia masih belum banyak mendapatkan prestasi pada cabang olahraga renang. Banyak faktor yang dapat mempengaruhi untuk mendapatkan prestasi pada cabang olahraga ini. Salah satu faktornya, seperti faktor anatomi (panjang lengan, tinggi badan, panjang tungkai); faktor fisiologi (kemampuan menghirup oksigen, kelincahan, keseimbangan, koordinasi, kekuatan, power, fleksibilitas); faktor biomekanika (kecepatan gerak, dan frekuensi kayuhan); faktor psikologi (kepribadian, atribusi, motivasi berprestasi, agresi, arausal, kecemasan, stress, aktivasi, kepemimpinan, komunikasi, komitmen, imagery, konsentrasi, konsep diri, dan rasa percaya diri). (Mulyana, 2013)

Dari beberapa faktor di atas, khususnya faktor psikologis belum banyak diteliti, maka dalam penelitian ini akan mengkaji hubungan antara kecemasan dan konsentrasi pada Atlet renang Petrokimia, Gresik.

Kecemasan merupakan suatu kondisi yang pernah dialami oleh hampir semua individu, hanya saja kadar dan tarafnya yang berbeda. Ada individu yang dapat menyelesaikan masalahmasalahnya hingga kecemasan yang dialami tidak berkepanjangan, tetapi tidak jarang kecemasan 
tersebut mendatangkan gangguan bagi yang mengalaminya (White \& Watt, 1981). Kecemasan dapat memiliki banyak gejala, biasanya kecemasan ditandai oleh perasaan-perasaan subyektif seperti ketegangan, ketakutan, kekhawatiran dan juga ditandai dengan aktifnya sistem syaraf pusat. Kecemasan biasanya timbul karena indivdu merasa terancam oleh suatu hal yang dianggap menakutkan dan menyakitkan baik dari dalam maupun dari luar dirinya (Kaplan dkk, 1997). Gangguan kecemasan dapat muncul sebagai akibat akumulasi dari frustrasi, konflik dan stres. Menurut Ayub, orang dengan gangguan kecemasan akan susah berkonsentrasi dan bersosialisasi sehingga akan menjadi kendala dalam menjalankan fungsi sosial, pekerjaan dan peranannya, sehingga berbagai langkah pencegahan dan penanggulangan harus segera dilakukan (Kompas, 2002).

Konsentrasi sendiri dapat diartikan sebagai suatu keadaan dimana kesadaran seseorang tertuju pada suatu objek tertentu dalam waktu tertentu (PBSI, 2001:59). Menurut Priambodo (2010: 7) konsentrasi adalah pemusatan pemikiran kepada suatu objek tertentu. Semua kegiatan manusia membutuhkan konsentrasi, dengan konsentrasi manusia dapat mengerjakan pekerjaan lebih cepat dan dengan hasil yang lebih baik. Sedangkan konsentrasi menurut Maksum (2011: 153) yaitu, istilah konsentrasi sering dialih-tukarkan dengan istilah perhatian, yaitu suatu keadaan dimana kesadaran seseorang tertuju kepada suatu objek tertentu dalam waktu tertentu. Dalam olahraga, konsentrasi sangat penting peranannya. Dengan berkurangnya atau terganggunya konsentrasi atlet pada saat latihan, apalagi pertandingan, maka akan timbul berbagai masalah. Terdapat faktor faktor yang dapat memengaruhi konsentrasi. Faktor internal dan eksternal, faktor internal yang memengaruhi konsentrasi yaitu usia, kondisi fisik, jenis kelamin, dan pengalaman. Sedangkan, menurut Gunarsa (2004:89) ada faktor-faktor eksternal yang dapat berpengaruh terhadap konsentrasi atlet, antara lain: a. Jika ada rangsang yang terlalu kuat, seperti bunyi yang sangat keras atau cahaya yang berkilau, seperi petir atau kilatan flash kamera. b. Jika rangsang yang datang adalah sesuatu yang tidak biasa atau sangat berbeda dengan rangsang-rangsang yang diterima, misalnya dalam ukuran atau jumlah. c. Jika rangsang yang sampai merupakan sesuatu yang luar biasa, yang tidak biasa ia dapatkan ditempat latihan. d. Jika rangsangnya bergerak sehingga perhatiannya tidak terpusat pada penglihatan yang sama, tidak monoton dan cenderung untuk melihat dengan asumsi dan dugaan ada sesuatu rangsang yang baru.

Berdasarkan fenomena yang terjadi pada atlet ketika bertanding, banyak atlet yang sering melakukan kesalahan saat dilihat oleh banyak orang. Ketika latihan atlet belum ada penonton yang banyak, sehingga dia merasa nyaman dan terbiasa akan hal itu. Tetapi ketika waktun bertanding tiba terkadang atlet canggung karena melihat lawannya yang lebih besar secara fisik atau bisa juga karena ia terbiasa sepi ketika latihan dan menjadi ramai ketika sedang bertanding. Sehingga, hal tersebut dapat membuat atlet mengalami kecemasan. Ketika atlet tersebut mengalami kecemasan maka konsentrasi dan segala persiapan yang telah disiapkan atlet tersebut menjadi kacau. Oleh karena itu, penelitian ini dilakukan bertujuan untuk mengetahui pengaruh antara kecemasan dan konsentrasi pada atlet renang Petrokimia Gresik.

\section{Metodologi Penelitian}

Metode yang digunakan adalah metode kuantitatif dengan menggunakan rancangan penelitian korelasi. Penelitian ini akan menghubungkan variabel kecemasan dengan variabel konsentrasi. Populasi penelitian ini adalah atlet renang Petrokimia gresik, dengan menggunakan sampel acak berjumlah 30 atlet. Teknik pengumpulan data pada penelitian ini dilakukan dengan memberikan skala yang diisi oleh sampel penelitian. Skala yang dibagikan kepada sampel penelitian terdiri atas dua skala yakni, skala kecemasan dan skala konsentrasi (grid concentration). Dimana salah satu dari kedua skala tersebut menggunakan model skala likert. Teknik analisis data yang digunakan oleh peneliti menggunakan teknik analisis product moment yang dibantu menggunakan program excel 2013 for windows 


\section{Hasil dan Pembahasan}

Hasil analisis dari penelitian ini mengenai hubungan antara kecemasan dengan konsentrasi pada atlet renang di Petrokimia Gresik . peneliti akan membahas mengenai hubungan atau korelasi antara kecemasan dengan konsentrasi. Dari tabel tersebut dapat diketahui bahwa nilai rata-rata untuk variabel konsentrasi sebesar 8,16 dengan nilai tertinggi sebesar 16 dan nilai terendah sebesar 2. Standart deviasi yang dimiliki oleh variabel konsentrasi sebesar 4,17. Sedangkan untuk variabel kecemasan memiliki nilai rata-rata sebesar 47 dengan nilai tertinggi sebesar 60 dan nilai terendah sebesar 34. Standart deviasi yang dimiliki oleh variabel kecemasan sebesar 7,37.

\section{Kategori Kecemasan}

\begin{tabular}{|l|l|l|}
\hline Kategori & Frekuensi & Prosentase \\
\hline $\mathbf{R}$ & 7 & $23,3 \%$ \\
\hline $\mathbf{S}$ & 23 & $76,7 \%$ \\
\hline $\mathbf{T}$ & - & $0 \%$ \\
\hline Total & $\mathbf{3 0}$ & $\mathbf{1 0 0 \%}$ \\
\hline
\end{tabular}

Berdasarkan hasil perhitungan, diketahui bahwa atlet yang mendapatkan nilai rendah adalah $23,3 \%$, yang mendapatkan nilai sedang adalah $76,7 \%$, dan lebih banyak mendapat nilai tinggi dengan prosentase $0 \%$.

\section{Kategori Konsentrasi}

\begin{tabular}{|l|l|l|}
\hline Kategori & Frekuensi & Prosentase \\
\hline $\mathbf{R}$ & 30 & $100 \%$ \\
\hline S & - & $0 \%$ \\
\hline $\mathbf{T}$ & - & $0 \%$ \\
\hline Total & $\mathbf{3 0}$ & $\mathbf{1 0 0 \%}$ \\
\hline
\end{tabular}

Berdasarkan hasil perhitungan di atas, diketahui bahwa atlet yang memiliki nilai rendah adalah $100 \%$, yang mendapatkan nilai sedang adalah $0 \%$, dan nilai tinggi dengan prosentase $0 \%$.

\subsection{Pembahasan}

Penelitian ini bertujuan untuk mengetahui adanya hubungan antara kecemasan dengan konsentrasi atlet renang Petrokimia Gresik. Dari hasil perhitungan korelasi di atas maka dapat diketahui bahwa untuk rhitung $=0,132$, jika nilai koefisien Pearson correlation (rxy) semakin mendekati 1, maka semakin kuat indikasi adanya korelasi (Priyatno, 2012) namun karena nilai koefisien korelasi berada dibawah 0,5 maka hubungan kecemasan dan konsentrasi tergolong lemah. Hal ini dapat diartikan bahwa kecemasan yang tinggi memiliki peran yang lemah dalam konsentrasi atlet renang Petrokimia Gresik.

Dari hasil penelitian kecemasan bawaan akan mempengaruhi konsentrasi atlet renang Petrokimia Gresik. Dengan demikian dapat diasumsikan bahwa semakin tinggi tingkat kecemasan atlet maka semakin rendah konsentrasi yang dimiliki para atlet. Hasil ini sesuai dengan prediksi teoritis bahwa ada hubungan dari kedua variabel tersebut, namun bertolak belakang dengan asumsi karena pada hasil penelitian ini kecemasan pada atlet renang Petrokimia Gresik tinggi namun konsentrasi yang dimiliki juga tetap tinggi sehingga kecemasan tidak sepenuhnya berpengaruh pada atlet. Sedangkan ada pula faktor lain yang mempengaruhi konsentrasi atlet menurut Gunarsa (2004:89) ada faktor-faktor eksternal yang dapat berpengaruh terhadap konsentrasi atlet, antara lain: a. Jika ada rangsang yang terlalu kuat, seperti bunyi yang sangat keras atau cahaya yang berkilau, seperi petir atau kilatan flash kamera. b. Jika rangsang yang datang adalah sesuatu yang tidak biasa atau sangat berbeda dengan rangsang-rangsang yang diterima, misalnya dalam ukuran atau jumlah. c. Jika rangsang yang sampai merupakan sesuatu yang luar biasa, yang tidak biasa ia dapatkan ditempat latihan. d. Jika rangsangnya bergerak sehingga perhatiannya tidak terpusat pada penglihatan yang sama, tidak monoton dan cenderung untuk melihat dengan asumsi dan dugaan ada sesuatu rangsang yang baru.

Hasil yang tidak sesuai dengan asumsi ini bisa dijelaskan sebagai berikut.

Pertama, temuan penelitian seperti ini kemungkinan terjadi karena tingkat kecemasan yang terjadi pada setiap individu memang berbeda dari satu individu dengan individu lain sehingga saat individu menjadi seorang atlet renang tidak begitu merasakan kecemasan seperti talet lainnya. 
Karena individu mengalami kecemasan apabila merasa ada suatu hal yang akan mengancam keberadaannya ataupun akan menyakiti individu tersebut namun berasal dari luar diri (Kaplan dkk, 1997).

Kedua, kecemasan yang terjadi pada atlet saat akan bertanding juga dapat diatasi dengan mudah oleh sebagian atlet sebab kecemasan dapat muncul sebagai akibat akumulasi dari frustrasi, konflik dan stress hal ini dapat diatasi dengan mudah oleh sebagian atlet karena mereka terbiasa berada dalam keadaan yang menekan. Menurut Ayub, orang dengan gangguan kecemasan akan susah berkonsentrasi dan bersosialisasi sehingga akan menjadi kendala dalam menjalankan fungsi sosial, pekerjaan dan peranannya, sehingga berbagai langkah pencegahan dan penanggulangan harus segera dilakukan (Kompas, 2002).

Dalam hal ini kecemasan yang tinggi pada atlet renang Petrokimia tidak mempengaruhi tingkat konsentrasi yang dimiliki, para atlet tetap fokus dengan pertandingan yang mereka ikuti pada saat itu. Sebagai contoh seorang atlet yang terus bergerak sebelum melakukan pertandingan di kolam renang hal ini juga mempengaruhi tingkat kecemasan semakin atlet bergerak maka ${ }^{\text {+incl }}$ ht kecemasan mereka juga semakin rendah, 79 a hanya berdiam diri otomatis rasa cemás yaug dirasakan akan semakin parah. Hal ini mempengaruhi tingkat kecemasan serta konsentrasi yang ada bukan hanya factor eksternal yang mempengaruhi namun juga factor internal dari dalam diri atlet sendiri.

\section{Simpulan dan Saran}

Dapat disimpulkan dalam penelitian ini bahwa ada hubungan antara kecemasan dengan tingkat konsentrasi pada atlet renang. Kesimpulan selanjutnya adalah karena adanya teoori-teori yang mendukung bahwa semakin tinggi tingkat kecemasan dari seorang atlet yang akan menghadapi pertandingan renang maka tingkat konsentrasi yang dimilki akan semakin rendah.

Kesimpulan pertama sesuai dengan hasil penelitian sebelumnya yang menunjukkan adanya hubungan antara kecemasan dan konsentrasi pada atlet renang di Petrokimia. Namun, kesimpulan kedua tidak sepenuhnya sesuai dengan asumsi teoritis yang memprediksi bahwa semakin tinggi kecemasan seseorang, semakin rendah konsentrasinya. Penelitian lebih lanjut perlu dilakukan terkait kecemasan dan tingkat konsentrasi seseorang yang berhubungan langsung dengan psikologis seseorang. Perbedaan karakteristik situasi dalam pertandingan dan lingkungan biasa menyebabkan adanya kemungkinan perbedaan dalam penjelasan perilaku dengan konteks lingkungan biasa dan lingkungan pertandingan

\section{Daftar Pustaka}

Gunarsa, S. D. 2004. Psikologi Olahraga Prestasi. Jakarta: BPK GunungMulia.

Hajidin., Nyak Amir. 2014. Pengembangan Alat Ukur Kecemasan. Jurnal Sport Pedagogy, Vol. 4(2), 26-28. (Online) . (http://www.jurnal.unsyiah.ac.id/JSP/artic le/download/7303/6003), diakses pada tanggal 30 April 2018

Kaplan, I., Sadock, B, J., \& Grebb, J, A. 1997. Sinopsis Psikiatri: Ilmu Pengetahuan Perilaku Psikiatri Klins Jilid 2 (Edisi Ketujuh) Alih Bahasa: Widjaja Kusuma. Jakarta: Birupa Aksara.

Maksum, Ali. 2011. Psikologi Olahraga Teori Dan Aplikasi. Surabaya. Unesa University Press.

Mulyana, Boyke. 2013. Hubungan Konsep Diri, Komitmen, dan Motivasi Berprestasi dengan Prestasi Renang Gaya Bebas. Jurnal Ilmiah Pendidikan UNY, 22(3), 488-489.

(Online)

(https://journal.uny.ac.id/index.php/cp/art icle/download/1636/pdf), diakses pada tanggal 1 Mei 2018.

Priambodo, A. dkk. 2010. Pengembangan Model Pelatihan Konsentrasi Untuk Meningkatkan Prestasi Atlet Bulutangkis. Laporan Penelitian. Surabaya. Kementrian 
Pendidikan Nasional Republik Indonesia:

Unesa.

PBSI. 2001. Pedoman Praktis Bermain

Bulutangkis.Jakarta: PBSI

Susanto, Ermawan. 2010. Manfaat Olahrag

Renang bagi Lanjut Usia. Jurnal Ilmiah

Kesehatan Olahraga, Vol. 6(1), 54.

(Online) .

(https://journal.uny.ac.id/index.php/medik ora/article/download/4669/4018), diakses pada tanggal 30 April 2018. 